\title{
Disaccharides and Cystic Fibrosis of the Pancreas*
}

\author{
I. S. E. GIBBONS $†$ \\ From The Hospital for Sick Children, Great Ormond Street, \\ and Institute of Child Health, Guilford Street, London
}

Disaccharide intolerance has been described in cystic fibrosis of the pancreas (Cozetto, 1963; Nordio et al., 1966; Sunshine and Kretchmer, 1964).

However, the relation between clinical signs and symptoms, and biochemical investigations is not clear. For instance, Cozetto (1963) reported isolated depressed lactase activity in an otherwise normal mucosa, but gave no clear clinical evidence in support of lactose intolerance. Two patients of Nordio et al. (1966) with cystic fibrosis of the pancreas showed evidence of disaccharidase deficiency in jejunal biopsies, and flat glycaemic responses to lactose, but disaccharide loads did not produce diarrhoea.

In this paper, an attempt has been made to correlate biochemical studies with clinical evidence of disaccharide intolerance. The term 'disaccharide intolerance' will be taken to mean, as suggested by Townley (1966), that there is 'the development of symptoms after ingestion of disaccharide and this is a clinically observed phenomenon'.

Seventeen children with cystic fibrosis of the pancreas have been investigated to determine whether intolerance to disaccharides from ordinary sources in the diet contributes to the gastrointestinal symptoms in this disease.

\section{Patients}

All the children studied were established cases of cystic fibrosis at The Hospital for Sick Children (Mantle and Norman, 1966) and were convalescent at the time of the tests; their ages ranged between 2 and 16 years. There was no interruption of treatment with antibiotics or pancreatic supplements. Three patients $(14,15$, and 16) had undergone resection of small bowel for meconeum ileus at birth.

Received July 11, 1968.

*This work was supported by a Grant from the Cystic Fibrosis Research Foundation Trust.

†Present address: Department of Pediatrics, The Hahnemann Medical College and Hospital, 230 North Broad St., Philadelphia 19102, P.A., U.S.A.

\section{Materials and Methods}

Urine was preserved with merthiolate. Stools were deep-frozen on solid carbon dioxide immediately after defaecation. Both red (carmine, $200 \mathrm{mg}$.) and blue (Edicol Supra Blue E.G., Imperial Chemical Industries Ltd., $10 \mathrm{mg}$.) markers were given by mouth as described in the investigations.

Sugars in urine and stools were examined by paper chromatography (Arthur et al., 1966). Total reducing substances in blood and urine were determined by a modification of the method of Folin and Wu (Wilkinson, 1960) and blood glucose by a modified glucose oxidase method (Hugget and Nixon, 1957).

Measurement of 3-O-methyl-D-glucose in urine. This sugar is considered to be actively absorbed in the gut, possibly along the same pathway as glucose, not metabolized by the body, and almost quantitatively excreted in the urine (Fordtran et al., 1962). It was decided to follow the excretion of this substance in the urine and stool to measure the total absorption of a monosaccharide.

Urines collected for the 3-O-methyl-D-glucose load (see investigations) were examined for sugars by paper chromatography (Arthur et al., 1966). The identification of reducing sugars except 3-O-methyl-D-glucose in any urines excluded that patient from the series. After desalting the urine for paper chromatography, an aliquot of the supernatant was diluted to a $1 \%$ solution with distilled water and $0.5 \mathrm{ml}$. taken for examination for total reducing substances. Non-specific reducing substances were measured in the baseline urine, and the result was subtracted from the figure for total reducing substances obtained on urine collected after the load. The quantitative measure of 3-O-methyl-D-glucose by the Folin and Wu method was checked for agreement against the quantitative measure for that sugar using paper chromatography.

\section{Investigations}

Excretion of sugars in urine on ward diet. 24-hour urines obtained from 52 patients with cystic fibrosis were examined for sugars. All were on a normal ward diet.

Increased carbohydrate diet. For 3 days the dietary carbohydrate (mostly sucrose with some lactose) 
TABLE I

Effect of Increased Dietary Sugar

\begin{tabular}{|c|c|c|c|c|c|c|}
\hline \multirow{2}{*}{ Case No. } & \multicolumn{2}{|c|}{ 24-hour Urine Sugars (mg./100 ml.) } & \multicolumn{2}{|c|}{ Stool Sugars (mg./100 g.) } & \multicolumn{2}{|c|}{ Stool Transit Time (hr.) } \\
\hline & Before Diet & On Diet & Before Diet & On Diet & Before Diet & On Diet \\
\hline 1 & None & None & None & $\begin{array}{l}\text { Lactose } 60 \\
\text { Sucrose } 10\end{array}$ & 22 & 25 \\
\hline 2 & Sucrose 30 & Sucrose 50 & None & Fructose 10 & 20 & 22 \\
\hline 3 & None & $\begin{array}{l}\text { Fructose } 20 \\
\text { Glucose } 20\end{array}$ & None & None & 22 & 23 \\
\hline 4 & None & None & None & Glucose 60 & 20 & 9 \\
\hline 5 & Sucrose 80 & None & None & None & 21 & 20 \\
\hline 6 & None & None & Glucose 10 & Galactose 150 & 33 & 36 \\
\hline 7 & $\begin{array}{l}\text { Sucrose } 100 \\
\text { Fructose } 20\end{array}$ & $\begin{array}{l}\text { Sucrose } 80 \\
\text { Fructose } 40\end{array}$ & None & None & 25 & 25 \\
\hline 8 & None & None & None & None & 18 & 20 \\
\hline 9 & $\begin{array}{l}\text { Sucrose } 40 \\
\text { Fructose } 15 \\
\text { Glucose } 500\end{array}$ & $\begin{array}{l}\text { Sucrose } 80 \\
\text { Glucose } 10\end{array}$ & Glucose 20 & None & 40 & 48 \\
\hline \multirow{4}{*}{$\begin{array}{l}10 \\
11 \\
12\end{array}$} & None & None & None & None & 22 & 23 \\
\hline & None & Glucose 10 & None & None & 25 & - \\
\hline & Sucrose 30 & Sucrose 150 & None & None & 20 & 24 \\
\hline & & Lactose 5 & & & Average 24 & 26 \\
\hline
\end{tabular}

of 12 patients was increased to $65 \%$ (normal $45 \%$ ) of the total daily calories. Blue and red markers were given at the beginning and end of the period respectively. On the last day of the diet, a 24-hour urine specimen and individual stools were collected and examined for sugars. In addition, stool transit times and any symptoms of nausea, vomiting, or abdominal cramps were recorded, and compared with the same studies when the patients were on a normal ward diet.

Mixed disaccharide load. The test was performed on 16 patients according to the method of Menzies and Seakins (1968). Equal parts of finely ground sucrose and lactose in a total dosage of 20,30 , and $40 \mathrm{~g}$. for children weighing $0-10,10-20$, and more than $20 \mathrm{~kg}$., respectively, were administered as a $10 \% \mathrm{w} / \mathrm{v}$ solution in water, together with a stool marker, after an overnight fast. Urine collected for 5 hours after the load plus one further specimen, and the marked stool, were examined for sugars.

Intolerance to this load (as well as to the individual disaccharide load) leads to clinical symptoms of nausea, vomiting, or abdominal cramps, and a shortened transit time of bowel contents of 2 to 10 hours. The biochemical findings are disacchariduria greater than $15 \mathrm{mg} . / 100 \mathrm{ml}$. and the presence of monosaccharide or disaccharide in the stool. In normals, under the conditions of the test, significant disacchariduria does not occur and the stools are free of sugar.

Sucrose load. A $10 \% \mathrm{w} / \mathrm{v}$ solution of sucrose in a dosage based on the Poulton-Payne dosage for glucose (Wilkinson, 1960) was administered to 15 children after an overnight fast. Urine and stool specimens were collected as for the mixed disaccharide load. Blood sugars were determined in a capillary sample obtained by finger prick before, and at 15 -minute intervals after, the load for 60 minutes.

Lactose load. This was performed by the same procedure as the sucrose load in 2 patients.

3-O-methyl-D-glucose load. This test was a modification of that of Nordio et al. (1965). A $5 \% \mathrm{w} / \mathrm{v}$ solution of 3-O-methyl-D-glucose in a dosage of $12 \mathrm{~g}$./ $1 \cdot 76 \mathrm{sq}$. m. body surface and a marker were administered to 14 patients after an overnight fast. A further drink of water was given 2 hours later to promote urine flow. Urine was collected for 9 hours after the load, and the marked stool was saved.

Peroral mucosal biopsy of jejunum. This was performed with a Crosby paediatric capsule using an image intensifier for accurate placement, and the specimen of mucosa was examined histologically, and preserved for measurement of enzymes, as described by Arthur (1966).

\section{Results}

Urinary excretion of sugars on ward diet. Of the 52 children studied, 26 excreted sucrose in amounts ranging from $30-500 \mathrm{mg} . / 100 \mathrm{ml}$., and $9 \mathrm{had}$, in addition, glucosuria $30-800 \mathrm{mg} . / 100 \mathrm{ml}$.

Effect of increased disaccharide diet. No patients refused the diet or had gastro-intestinal symptoms. Stool transit time was reduced in only one patient (Case 4).

The excretion of sugars in urine and stools when the patients received (a) an ordinary ward diet, (b) the excessive sugar are shown in Table I. 
Sugars were found in the stools of 2 children before the diet and in 4 on the diet. 4 patients had sucrosuria both before and on the diet, while significant glucosuria was found in one child before the increased carbohydrate was given.

Mixed disaccharide load. 9 of the patients given this load had previously shown significant disacchariduria on the normal ward diet, but only 3 did so after the load. Only one patient (Case 15) produced a clearly abnormal response. After the load he had abdominal discomfort, and 8 hours later passed a loose stool containing lactose and glucose (normal transit time in this patient, 14 hours). In addition he had lactosuria and sucrosuria. One other child (Case 16) showed glucose in the stool and a shortened transit from 23 to 8 hours. However, there was no abdominal discomfort and no sugars were found in the urine (Table II). Despite the appearance of sugars in the stools of 5 others, all patients apart from Cases 15 and 16 were asymptomatic.

Sucrose load. The blood sugars from 15 children are shown in Table III. In no instance did the blood glucose or total reducing substances fail to rise $30 \mathrm{mg}$. $/ 100 \mathrm{ml}$. or more above the baseline when taken at 15-minute intervals. In all except 3 patients (Cases 1, 11, and 14) the blood glucose peak was reached at 30 minutes and was beginning to fall again at 45 minutes.

Six children produced monosaccharides and disaccharides in their stools, but did not have any sugars in the urine. The stool transit time was
TABLE II

Effect of Mixed Disaccharide Load

\begin{tabular}{|c|c|c|c|}
\hline Patient & $\begin{array}{l}\text { Sugars in } \\
\text { Urine after } \\
\text { Load } \\
\text { (mg. } / 100 \mathrm{ml} .)\end{array}$ & $\begin{array}{l}\text { Sugars in Marked Stool } \\
\text { (mg./100 g.) }\end{array}$ & $\begin{array}{l}\text { Stool } \\
\text { Transit } \\
\text { Time } \\
\text { (hr.) }\end{array}$ \\
\hline 1 & None & Lactose 60 & 24 \\
\hline 13 & None & None & 20 \\
\hline 14 & Glucose 60 & None & 23 \\
\hline 15 & $\begin{array}{l}\text { Sucrose } 60 \\
\text { Lactose } 150 \\
\text { Fructose } 5 \\
\text { Galactose } 5\end{array}$ & $\begin{array}{l}\text { Lactose } 50 \\
\text { Glucose } 80\end{array}$ & 8 \\
\hline 2 & $\begin{array}{l}\text { Lactose } 50 \\
\text { Galactose } 25\end{array}$ & $\begin{array}{l}\text { Sucrose } 10 \\
\text { Fructose } 5\end{array}$ & 71 \\
\hline 3 & None & None & 23 \\
\hline 4 & Glucose 100 & $\begin{array}{l}\text { Sucrose } 10 \\
\text { Lactose } 10 \\
\text { Glucose } 10 \\
\text { Galactose } 10 \\
\text { Fructose } 10\end{array}$ & 22 \\
\hline 5 & None & Glucose 10 & 22 \\
\hline 6 & None & None & 一 \\
\hline 7 & None & $\begin{array}{ll}\text { Sucrose } 120 & \text { Lactose } 20 \\
\text { Galactose 10 } & \text { Glucose } 80 \\
\text { Fructose 200 } & \end{array}$ & 21 \\
\hline 8 & $\begin{array}{l}\text { Sucrose } 60 \\
\text { Lactose } 80 \\
\text { Fructose } 15 \\
\text { Galactose } 60\end{array}$ & None & 22 \\
\hline 16 & None & Glucose 80 & 8 \\
\hline 9 & None & None & 46 \\
\hline 10 & None & None & 22 \\
\hline 11 & None & None & 22 \\
\hline 17 & None & Fructose 10 & 14 \\
\hline
\end{tabular}

shortened to 8 and 9 hours in 2 of these only (Cases 5 and 14). Significant sucrosuria occurred in 5 children, ranging from 40 to $400 \mathrm{mg}$. $/ 100 \mathrm{ml}$. Only one of these had sugar in the stool, but the transit time was normal (Table IV). Clinical

TABLE III

Glycaemic Responses to a Sucrose Load

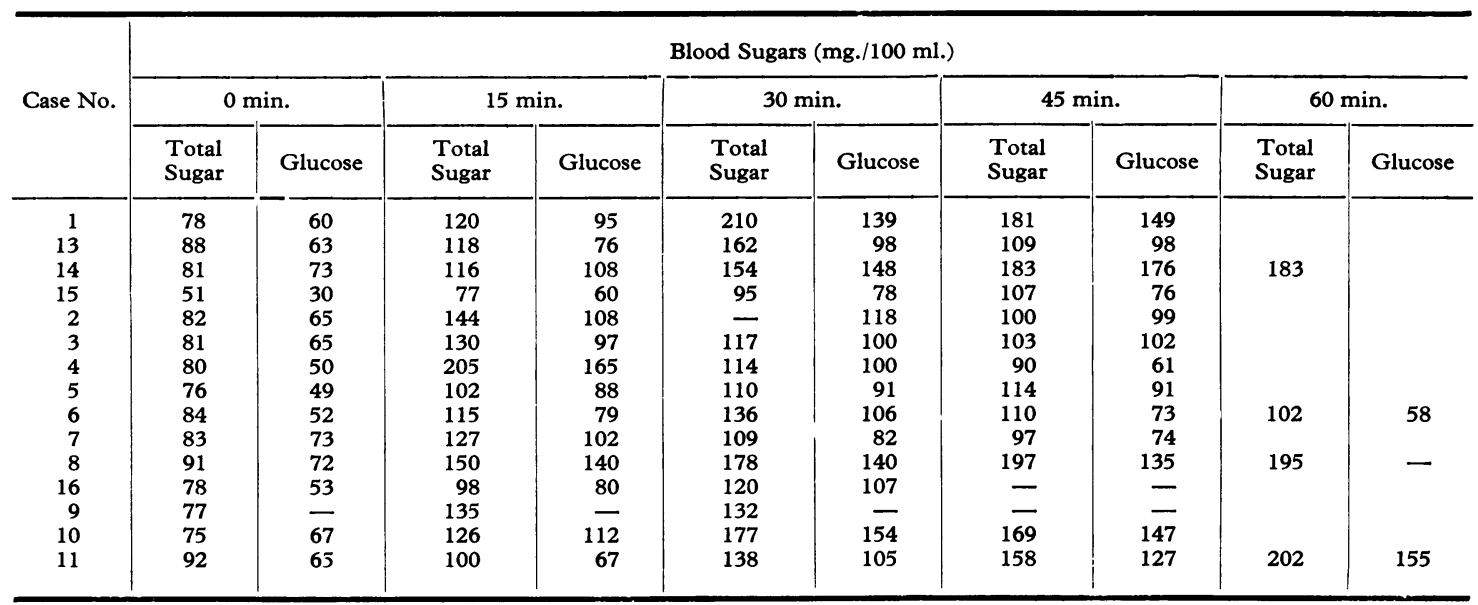


TABLE IV

Urine and Stool Findings after

a Sucrose Load

\begin{tabular}{|c|c|c|c|}
\hline Case No. & $\begin{array}{l}\text { Sugars in Urine } \\
\text { after Load } \\
\text { (mg. } / 100 \mathrm{ml} .)\end{array}$ & $\begin{array}{c}\text { Sugars in } \\
\text { Marked Stool } \\
(\mathrm{mg} . / 100 \mathrm{~g} .)\end{array}$ & $\begin{array}{l}\text { Stoul Transit } \\
\text { Time (hr.) }\end{array}$ \\
\hline 1 & $\begin{array}{l}\text { Sucrose } 300 \\
\text { Fructose } 50 \\
\text { Glucose } 2400\end{array}$ & Glucose 10 & 24 \\
\hline 13 & Sucrose 60 & None & 21 \\
\hline 14 & None & Glucose 30 & 9 \\
\hline 15 & $\begin{array}{l}\text { Sucrose } 400 \\
\text { Fructose } 5\end{array}$ & None & 22 \\
\hline 2 & None & Glucose 50 & 22 \\
\hline 3 & Sucrose 40 & None & 21 \\
\hline 4 & None & $\begin{array}{l}\text { Sucrose } 10 \\
\text { Fructose } 10\end{array}$ & 22 \\
\hline 5 & None & $\begin{array}{l}\text { Sucrose } 20 \\
\text { Fructose } 20 \\
\text { Glucose } 100\end{array}$ & 8 \\
\hline 6 & None & None & - \\
\hline 7 & None & None & 22 \\
\hline 8 & None & None & 22 \\
\hline 16 & None & None & 23 \\
\hline 9 & Sucrose 80 & None & 30 \\
\hline 10 & None & None & 23 \\
\hline 11 & None & Glucose 10 & 21 \\
\hline
\end{tabular}

TABLE V

3-O-Methyl-D-Glucose Load

\begin{tabular}{c|cc}
\hline Case No. & $\begin{array}{c}\text { \% of Dose Excreted } \\
\text { in } 9 \mathrm{hr} .\end{array}$ & $\begin{array}{c}\text { 3-O-methyl-D-glucose } \\
\text { in Stool (mg./100 g.) }\end{array}$ \\
\hline 1 & 73 & None \\
13 & 61 & None \\
14 & 64 & None \\
15 & 42 & None \\
2 & 62 & Trace \\
3 & 63 & None \\
4 & 58 & None \\
5 & 70 & 40 \\
6 & 31 & None \\
7 & 63 & None \\
9 & 60 & None \\
10 & 75 & None \\
11 & 68 & None \\
17 & 79 & None \\
\hline
\end{tabular}

TABLE VI

Effect of Lactose Load in 2 Selected Patients

\begin{tabular}{c|ccc}
\hline Case No. & $\begin{array}{c}\text { Sugar in Urine } \\
\text { After Load } \\
(\mathrm{mg} / 100 \mathrm{ml} .)\end{array}$ & $\begin{array}{c}\text { Sugar in Marked } \\
\text { Stool } \\
(\mathrm{mg} . / 100 \mathrm{~g} .)\end{array}$ & $\begin{array}{c}\text { Stool Transit } \\
\text { Time (hr.) }\end{array}$ \\
\hline 15 & Lactose 60 & $\begin{array}{l}\text { Lactose }>500 \\
\text { Galactose }>400 \\
\text { Glucose }>200 \\
\text { None }\end{array}$ & 61 \\
\hline
\end{tabular}

and biochemical evidence did not correlate to support intolerance in any of the children studied.

3-O-methyl-D-glucose load. The normal excretion in urine collected up to 9 hours after the load is given by Nordio et al. (1965) as ranging widely from 55 to $100 \%$ of the dose given. On this basis only 2 out of 14 children given the load were clearly abnormal; Case 6 with $30 \%$ and Case 15 with $42 \%$ (Table V). The excretion by Case 6 remains unexplained, as none of her other tests suggested abnormal handling of sugars. She continued to excrete 3-O-methyl-D-glucose in the urine for 4 days.

Lactose load. The results on 2 patients (Cases 15 and 16) are shown in Table VI. These children ( 2 of the 3 who had undergone small bowel resection at birth) were selected for a lactose load because both developed symptoms after the mixed disaccharide load and neither had proved intolerant to sucrose.

One patient (Case 15) produced a frankly abnormal response with some abdominal cramps, disaccharides in urine and stool, and a loose stool with a short transit time.

Case 16 did not produce disaccharides in urine or stool, but the stool transit time was shortened from a usual 23 hours for this patient to 10 hours.

Jejunal biopsy. This was reserved for those patients who showed intolerance to disaccharides by both clinical and biochemical tests. On this basis only one patient (Case 15) qualified. The biopsy showed a flattened mucosa with villous atrophy, and reduced activity of disacchar:dases, especially lactase. Lactase activity was 0.15 units (normal $>2.5$ ), sucrase 0.54 units (normal $>3.0$ ), and maltase $5 \cdot 4$ units (normal $>10 \cdot 0$ ), all per $\mathrm{g}$. wet weight of mucosa.

\section{Discussion}

The occurrence of disacchariduria in half of the children studied on a ward diet, and the high carbohydrate diet, is consistent with similar findings by Gryboski et al. (1963). Sucrosuria has been shown in normal children and in those with cystic fibrosis of the pancreas, and may be partly related to the concentration of the sugar reaching the small bowel mucosa (Menzies and Seakins, 1968). On a normal or high carbohydrate diet this concentration may be sufficiently hypertonic to cause sucrosuria. Using the sugar load technique described overcomes this difficulty, and disacchariduria due to dietary variation is easily distinguished from that due to disaccharide malabsorption. 
Glucosuria greater than $30 \mathrm{mg} . / 100 \mathrm{ml}$. occurred in 9 of 52 cases. Whether the findings represent a lowered renal threshold to glucose or are indicative of a latent diabetic state is not clear, but one child (Case 14) developed diabetes mellitus with ketosis 12 months later.

Increasing the dietary sugar for 3 days produced no clinical evidence of malabsorption except that one patient (Case 4) had a shortened stool transit time. She had no symptoms and on subsequent testing was not shown to be intolerant of any particular sugar. The reason for the short transit time remains unexplained.

At this hospital the mixed disaccharide load has proved a useful screen for suspected intolerance in children who are not severely ill. The two children (Cases 15 and 16), who reacted to the mixed disaccharide load, on further testing were not intolerant of sucrose. However, a lactose load on Case 15 produced all the biochemical and clinical criteria of intolerance, while in Case 16 it produced only a shortened stool transit time. The clinical evidence of lactose intolerance in this latter child was not supported by the biochemical studies, but he presumably had some depressed lactase activity which led to a clinical reaction under the load conditions.

Results of the sucrose load show the dangers of placing faith in one particular test of intolerance. All the glycaemic responses were normal, in terms of the rate of rise of blood sugar, but 10 out of 15 cases showed some other biochemical abnormality either in the urine or stool, or both. Though these 10 children were not coping entirely normally with the load conditions, only 2 (Cases 5 and 14) showed clinical intolerance. The biochemical findings in these 2 did not correlate with the clinical evidence of intolerance to sucrose.

The appearance of significant sucrosuria in many children with cystic fibrosis suggests that sucrose moves unchanged across the bowel wall more easily than in the normal child. This does not necessarily mean that such cases are intolerant of sucrose.

Only 2 of the 14 children tested with 3-O-methylD-glucose were clearly abnormal. One of these (Case 15) was proved intolerant of lactose. This suggests that with the exception of this child, there was no severe impairment of the total absorption of the monosaccharide glucose in the other 12 .

The correlation of biochemical and clinical evidence of intolerance to lactose, together with impaired total active monosaccharide absorption, led to biospy in one child (Case 15). It is possible that if more of these children had been subjected to biopsy they would have revealed some depression of sucrase and especially lactase activity. Case 15 was not intolerant of sucrose though the area of biopsy showed considerably depressed sucrase activity. However, like many of the other children this case frequently produced sucrosuria. It is clear, therefore, that depressed disaccharidase activity is not always synonymous with clinical and biochemical intolerance.

Villous atrophy has been reported before in cystic fibrosis (Nordio et al., 1966), but most biopsies in this disease show a normal mucosa (Rubin and Dobbins, 1965). Both Cases 15 and 16 showed intolerance of lactose and both had small bowel resections in infancy. In this respect they can be compared with the case reported by Sunshine and Kretchmer (1964) in which half the ileum, caecum, and ascending colon had been resected at birth. The only other child (Case 14) who had undergone bowel resection in infancy did not have disaccharide intolerance.

This study has not included the age-group below 2 years when of course lactose is more important. Those children who have had small bowel resection for meconium ileus appear more likely to be affected by lactose intolerance, just as any neonate with small gut resection (Burke and Anderson, 1966). The mixed disaccharide load detects the disaccharide-intolerant infant as easily as the older child

Sugars are commonly found in the urine and stools of many children with cystic fibrosis. This suggests that such children may not deal normally with disaccharides. Results of further investigations do not suggest that this malabsorption of disaccharides contributes to the gastro-intestinal symptoms, except when clinical and biochemical evidence suggests frank intolerance.

The decision to modify the disaccharide content of the diet in cystic fibrosis should be based on correlated clinical and biochemical evidence of intolerance. The method of sugar load used in this study, which does not require blood specimens, is an advantage in children. The difficulty of interpretation of glycaemic responses is avoided (Nordio et al., 1965; Holt and Somersalo, 1966). Disaccharide intolerance should be considered in children with cystic fibrosis who have had bowel resection for meconium ileus, or who appear to have more than usually severe gastro-intestinal signs and symptoms.

\section{Summary}

Seventeen children with cystic fibrosis of the pancreas have been examined for evidence of disaccharide intolerance. Both a normal and a high 
carbohydrate diet produced sugars in the urine or stools of half the patients. Correlation of the clinical response with biochemical abnormalities after disaccharide loads showed frank intolerance to lactose in one child who had undergone bowel resection for meconium obstruction. Disaccharide intolerance should be considered in children with cystic fibrosis who have had bowel resection for meconium ileus, or who appear to have more than usually severe gastro-intestinal signs and symptoms. The method of sugar load used, which does not require blood specimens, is useful for children.

I thank Dr. A. P. Norman, Hospital for Sick Children, who suggested this investigation, and Dr. B. E. Clayton, Department of Chemical Pathology, for helpful advice. Dr. J. W. T. Seakins and the Department of Analytical Biochemistry gave valuable assistance. The high standard of nursing in Ward 2CD (Sister H. Wood) and at the Tadworth Country Branch (Sister J. Mayes) made this study possible.

\section{REFERFNCES}

Arthur, A. B. (1966). Intestinal disaccharidase deficiency in children with coeliac disease. Arch. Dis. Childh., 41, 519.

-, Clayton, B. E., Cottom, D. G., Seakins, J. W. T., and Platt, J. W. (1966). Importance of disaccharide intolerance in the treatment of coeliac disease. Lancet, 1, 172.

Burke, V., and Anderson, C. M. (1966). Sugar intolerance as a cause of protracted diarrhoea following surgery of the gastrointestinal tract in neonates. Aust. paediat. F., 2, 219.

Cozetto, F. J. (1963). Intestinal lactase deficiency in a patient with cystic fibrosis. Pediatrics, 32, 228.

Fordtran, J. S., Clodi, P. H., Soergel, K. H., and Ingelfinger, F. J. (1962). Sugar absorption tests, with special reference to 3-O-methyl-D-glucose and d-xylose. Ann. intern. Med., $57,883$.

Gryboski, J. D., Thayer, W. R., Jr., Gabrielson, I. W., and Spiro, H. M. (1963). Disacchariduria in gastrointestinal disease. Gastroenterology, 45, 633.

Holt, L. E., Jr., and Somersalo, O. (1966). The measurement of carbohydrate intolerance. Helv. paediat. Acta, 21, 588.

Hugget, A. St. G., and Nixon, D. A. (1957). Use of glucose oxidase, peroxidase and O-dianisidine in determination of blood and urinary glucose. Lancet, 2, 368.

Mantle, D. J., and Norman, A. P. (1966). Life-table for cystic fibrosis. Brit. med. F., 2, 1238.

Menzies, I. S., and Seakins, J. W. T. (1968). Sugar loading test. In Chromatographic and Electrophoretic Techniques, 2nd ed., Vol. I. Ed. by I. Smith. Heinemann, London.

Nordio, S., Lamedica, G. M., Berio, A., and Vignolo, L. (1966). Disaccharidase activities of duodenal mucosa in children. Ann. paediat. (Basel), 206, 287.

, - Vignolo, L., and Berio, A. (1965). Problems regarding intestinal absorption of monosaccharides. The 3-methyl-Oglucose test. ibid., 204, 157.

Rubin, C. E., and Dobbins, W. O., III (1965). Peroral biopsy of the small intestine. A review of its diagnostic usefulness. Gastroenterology, 49, 676.

Sunshine, P., and Kretchmer, N. (1964). Studies of small intestine during development. III. Infantile diarrhea associated with intolerance to disaccharides. Pediatrics, 34, 38 .

Townley, R. R. W. (1966). Disaccharidase deficiency in infancy and childhood. ibid., 38, 127.

Wilkinson, R. H. (1960). Chemical Micromethods in Clinical Medicine. Thomas, Springfield, Illinois; Blackwell, Oxford. 